DOI: 10.20472/IAC.2017.034.047

\title{
EVA RIEVAJOVÁ
}

University of Economics in Bratislava, Faculty of National Economy, Department of Social Development and Labour, Slovak Republic

\section{ROMAN KLIMKO}

University of Economics in Bratislava, Faculty of National Economy, Department of Social Development and Labour, Slovak Republic

\section{DIFFERENCES BY GENDER ON THE SLOVAK LABOUR MARKET}

\begin{abstract}
:
Gender differences between men and women may manifest in any area, such as the gender inequality of men and women, as well as rights and inequalities in the labour market. In recent years, one of the issues discussed in economically advanced countries is the issue of equal opportunities for men and women in the labour market. These differences may be due to different nationality, gender, age, religion or sexual orientation. With respect to the labour market, we focused on gender discrimination, i.e. the different positions of men and women in individual labour market areas on the basis of their gender. The aim of this paper is to identify and evaluate the development of gender differences in the Slovak labour market in the context of global understanding of this issue and to determine whether these differences have a growing trend or are on the decline. Additionally, the paper set out to find in which job positions these differences are the most pronounced. The theoretical approaches and legislative norms governing the equal status of men and women are the basis for this paper. This is followed by an analysis of the development and the current status of women in the Slovak labour market.
\end{abstract}

\section{Keywords:}

labour market, gender discrimination, wage differences, educational attainment, Slovakia

JEL Classification: J08, J21, J64 


\section{Introduction}

Many studies and analyses show that women are still at a disadvantage either in terms of access to jobs or jobs in professions that are worse paid. Despite the fact that women study longer than men, their earnings are lower and there are few women in higher managerial positions. In recent years, one of the issues discussed in economically advanced countries is the issue of equal opportunities for men and women in the labour market. In all the studied countries we are seeing on the one hand the preferential treatment of individuals and, on the other hand, with a double standard applied in the treatment of individuals on the labour market. These differences may be due to different nationality, gender, age, religion or sexual orientation. There are many changes in the world today and the labour market is no exception. These changes include globalization, migration, economic integration, the increased importance of knowledge, and the aging of the population. All of these factors significantly affect the structure of the workforce.

The aim of the paper is to identify and evaluate the development of gender differences on the Slovak labour market in the global context, and secondly, whether these differences tend to grow or diminish, and also to point out the areas in the labour market where these differences are the most pronounced.

\section{Gender Discrimination in Theory and Legislation}

On the basis of the first written records, we can assess that there was an unequal status of men and women in our country already in the past. In the past women were under the tutelage of their father, and when they got married, this guardianship was assumed by their husband who had the right to the wife's property. When the 1874 law stipulated that women become independent when they reach adulthood. Nevertheless, such laws were, at that time, rather an exception than a rule. Already in 1997, the difference between men's and women's wages was approximately $21 \%$.

From time immemorial, work has been divided to male and female work, with men being responsible for ensuring for family livelihoods (hunting), or the man was understood to hold the role as a breadwinner of the family. The woman was primarily a mother, and her role was closely related to family and household care. This work was mostly done at home, so such a role was considered as taken for granted.

Women could not be educated to the same extent as men, because their education has long been denied to them. Nevertheless, the industrial revolution brought new changes. The biggest change was that women started to do work for which they received a financial reward. Despite the changes brought about by the industrial revolution, women's opportunities remained limited. Women were mostly employed in jobs related to the care of people or household. The financial reward for their work was lower than that of their male counterparts, even for the same job. The main reason for this difference is the fact 
that women were seen as an unstable workforce due to maternity, and also that women's income was a "supplementary" income for the family (Pietruchová, 2007, p. 46).

Within the EU, many documents have been enacted to ensure the equal status of women and men, including the following ones:

- Treaty establishing the European Economic Community (EEC) 1957 - this Treaty (Article 119) contains the principle of equal pay for men and women;

- Amsterdam Treaty of 1997 - this Treaty amends Article 119 of the EEC Treaty to Article 141; this Treaty includes as one of its priorities equality between men and women;

- The European Employment Strategy (1997) - based on it, the four pillars of the strategy were established, with one pillar representing equal opportunities in the labour market;

- Charter of Fundamental Rights of the European Union (2000) - Article 15 provides for free choice of occupation and right to work, Article 21 - Nondiscrimination, Article 23 - Equality between women and men (EU Charter of Fundamental Rights, 2000).

- The Treaty of Lisbon (2009) - this Treaty included all articles on gender equality within a single EU framework;

- Women's Charter - The Commission adopted this Charter in 2010, which seeks to achieve gender equality and at the same time strengthen gender equality in all its policies;

- The Commission's Strategy for equality between men and women - set up for 2010-2015, at the outset of this strategy, it is said that equality is one of the five values on which the Union is founded.

\section{Gender Segregation of Professions is addressed by Three Basic Theories:}

1. The theory of a neoclassical model / model of human capital;

2. Institutional theories and theories of labour market segmentation;

3. Non-economic and feminist theories.

\section{The Neoclassical Model / Model of Human Capital}

The Theory of Human Capital was drafted by Gary Becker. "Human Capital analysis is based on the assumption that individuals are deciding on their education, work, medical care, and other complementary knowledge and health based on a comparison of 
earnings and costs. Revenue includes, besides improving earnings and employment, both cultural and other profits, while the costs usually depend on the time spent earning these investments" (Becker, 1997, p. 195).

According to this theory, the lower earnings of women is the result of their choice, which is conditional on the priorities of women and men in choosing a job. Women mostly invest in areas that satisfy them, but are not reflected in the return on investment they have made in these areas. According to Becker, the main concern of women is to concentrate attention on their family and household care, and therefore women choose less demanding occupations (IVPR, 2006).

Both of these theories are based on the assumption that employers and employees behave rationally and also anticipate the efficient functioning of the market. Employees try to find the best paid jobs, taking into account their personal abilities, limitations and preferences. Employers try to maximize their profits, maximize labour productivity at the lowest possible costs (IVPR, 2006).

\section{Institutional Theories and Theories of Labour Market Segmentation}

These theories explain why the male and female occupations are segmented or divided between the primary and secondary sectors. In the primary sector, we include occupations that are characterized by higher wages, better workplace opportunities and also job security. Enterprises in this sector prefer men over women because they consider the former to be more educated and skilled. Women are under-represented in this sector, due to a break due to pregnancy and maternity leave. The secondary sector includes professions that we could call "women's professions." Typical features for these occupations are lower wages, limited chances for career advancement, and also worse working conditions. This sector is exposed to tougher competition (IVPR, 2006).

\section{Non-economic and Feminist Theories}

Feminist theories consider the disadvantaged position of women in the labour market to reflect the patriarchal approaches and subordinate status of women in family and society (Barošová, 2006). In all societies, domestic work and childcare are considered to be the responsibility of women. On the other hand, the role of men is to provide for a family, men are referred to as "family breadwinners". Such a division of labour determines what knowledge and skills should be available to men and what to women in terms of their family tasks. Such a division means that women have decreased opportunities to accumulate human capital compared to the male gender before entering the labour market. This is a consequence of why women are less educated, and women are less inclined to continue in certain areas of study, such as technical sciences. 


\section{Development and Current Status of Women on the Slovak Labour Market}

Examining the differences between men and women shows that women's discrimination in the world persists despite the various legislative measures. In the Slovak Republic, the male employment rate is $75 \%$, while the employment rate for women is $59.9 \%$ (2015). By age group, employment in 2015 compared to 2014 increased in all age categories, especially for the benefit of workers aged 55 and over. For this age category, the number of working people grew by up to 23,000 , of which 17,000 were women. The largest percentage $(30 \%)$ of the total number of workers is represented by people aged $35-44$ years (Statistical Office of the SR, 2016).

Table 1 shows the number of workers in the Slovak Republic by age group. A decreasing trend can be seen in the younger age group of 15-34 and also in the 45-54 age group. The number of workers aged 55 and over grew by 105,000 in 2015 compared to 2009.

Table 1: Employees in the Slovak Republic in thousands (April 2016)

\begin{tabular}{|c|c|c|c|c|c|c|c|}
\hline Age groups & 2009 & 2010 & 2011 & 2012 & 2013 & 2014 & 2015 \\
\hline 15 - 24 yrs & 185 & 163 & 151 & 146 & 144 & 148 & 154 \\
\hline $25-34$ & 678 & 654 & 630 & 626 & 612 & 599 & 620 \\
\hline $35-44$ & 621 & 620 & 628 & 640 & 661 & 694 & 702 \\
\hline $45-54$ & 622 & 604 & 610 & 598 & 581 & 579 & 582 \\
\hline $\begin{array}{l}55 \text { yrs and } \\
\text { over }\end{array}$ & 260 & 277 & 296 & 318 & 331 & 342 & 365 \\
\hline Total & 2366 & 2318 & 2315 & 2328 & 2329 & 2362 & 2424 \\
\hline
\end{tabular}

Source: Own calculations based on data from STATISTICAL OFFICE OF THE SR.

Differences between men and women also prevail in education. Women are mostly interested in humanitarian and economic majors, and men focus on technical curriculum. We can also include the area of higher education as an area of gender diversity, because women account for the majority of university students. In 2015 , the share of women in the total number of college graduates was $59.58 \%$. In the Slovak Republic, in the age group $25-34,30 \%$ of the population has attained university education, but only $24 \%$ of men and $36 \%$ of women (Ministry of Education of the SR, 215). These values are well below the Europe 2020 target of $40 \%$.

Women work predominantly in sectors and professions such as health, education, social care, commerce, etc. where the wage is below the average wage in the economy. Some professions have typically become female, such as nurses, tailors, salespersons, or teachers in kindergartens. As typically male occupations we can include mason, truck 
driver, pilot and others. Thus, we can conclude that men are over-represented in positions that are more financially valued.

In the following table 2, we can see the numbers of women and men employed in the Slovak Republic based on education. The table shows that men and women are more represented in lower secondary and completed secondary education. Women are also more represented in the field of higher education, although men dominate positions in higher tier jobs.

Table 2: Working women and men based on education in Slovak Republic in thousands (April 2016)

\begin{tabular}{|l|c|r|r|r|r|r|r|r|}
\hline \multicolumn{1}{|c|}{ Education } & & 2009 & 2010 & 2011 & 2012 & 2013 & 2014 & 2015 \\
\hline \multirow{2}{*}{ Primary and none } & Women & 46 & 45 & 48 & 46 & 48 & 46 & 50 \\
\cline { 2 - 9 } & Men & 47 & 47 & 43 & 42 & 44 & 40 & 48 \\
\hline \multirow{2}{*}{ Lower secondary } & Women & 268 & 240 & 237 & 244 & 241 & 240 & 235 \\
\cline { 2 - 9 } & Men & 530 & 512 & 494 & 503 & 459 & 438 & 437 \\
\hline $\begin{array}{l}\text { Completed } \\
\text { secondary }\end{array}$ & Women & 524 & 516 & 504 & 493 & 495 & 492 & 502 \\
\cline { 2 - 10 } & Men & 544 & 508 & 530 & 535 & 552 & 580 & 599 \\
\hline \multirow{2}{*}{ Higher } & Women & 202 & 233 & 234 & 242 & 250 & 268 & 288 \\
\cline { 2 - 9 } & Men & 206 & 217 & 225 & 223 & 240 & 258 & 265 \\
\hline
\end{tabular}

Source: Own calculations based on: STATISTICAL OFFICE OF THE SR.

In the next section, we will list the jobs in which men earn more than women and also give reasons why women earn less. The main reason is the maternity leave and, as a result, women get delayed in attaining higher positions.

In Table 3, we can see jobs where men earn significantly more than women. The difference between their salaries is almost third, ranging from $25 \%$ to $43 \%$. The biggest difference between the salary of men and women can be seen in the position of the chef, this difference represents up to $43 \%$. A man in this position earns 1,303 EUR compared the woman who earns just 747 EUR. 
Table 3: Jobs where men earn significantly more than women (March 2016)

\begin{tabular}{|l|c|c|c|}
\hline \multirow{2}{*}{$\begin{array}{c}\text { Jobs where men earn significantly more than } \\
\text { women }\end{array}$} & \multicolumn{2}{|c|}{$\begin{array}{c}\text { Earnings in } \\
\text { EUR/month }\end{array}$} & $\begin{array}{c}\text { Difference } \\
\text { in \% }\end{array}$ \\
\cline { 2 - 3 } & Male & Female & \\
\hline Chef & 1303 & 747 & $43 \%$ \\
\hline Manager for operations & 2132 & 1405 & $34 \%$ \\
\hline Leader of a sales group & 1787 & 1242 & $30 \%$ \\
\hline Cook & 769 & 566 & $26 \%$ \\
\hline Financial agent & 1119 & 842 & $25 \%$ \\
\hline
\end{tabular}

Source: Own calculations based on PLATY.SK.

In some jobs, women's wages are higher than men's, as can be seen in Table 4. However, despite this fact, it can be noted that these differences are smaller and range from $9 \%$ to $17 \%$. Thus, occupations where women earn more include the following: computer network administrator, clinical studies monitor, process engineer, tax adviser assistant, and product manager.

The widest gender pay gap is seen in the 35-44 age bracket, where women's wages are around 850 EUR, while men's wages are around 1200 EUR.

Table 4: Occupations women earn more than men (March 2016)

\begin{tabular}{|l|c|c|c|}
\hline \multirow{2}{*}{ Occupations women earn more than men } & \multicolumn{2}{|c|}{$\begin{array}{c}\text { Earnings } \\
\text { EUR/month }\end{array}$} & \multirow{2}{*}{$\begin{array}{c}\text { Difference } \\
\%\end{array}$} \\
\cline { 2 - 3 } & Male & Female & \\
\hline Computer network administrator & 1125 & 1316 & $17 \%$ \\
\hline Clinical studies monitor & 1667 & 1925 & $15 \%$ \\
\hline Process engineer & 1199 & 1375 & $15 \%$ \\
\hline Tax adviser assistant & 1175 & 1330 & $13 \%$ \\
\hline Product manager - specialist & 1570 & 1714 & $9 \%$ \\
\hline
\end{tabular}

Source: Own calculations based on PLATY.SK.

\section{Slovakia through the Prism of Global Gender Gap Index}

The Global Gender Gap Index was created in 2006 and is compiled and published by the World Economic Forum. This index is based on three basic "pillars" or terms. The first pillar is focused on measuring differences rather than levels. As an example, we can list well-to-do countries that can offer better education and health care services. Another pillar focuses on capturing the gaps in resulting variables as gaps in input variables. The variables that are examined include the comparison of differences between men and women in highly qualified jobs (managers, legislators) without taking into account data on 
the length of maternity leave. The main task of the third, the last pillar, is to organize countries by gender equality rather than by women's domination. It is focused on finding whether the differences between men and women are shrinking. Situations when women achieve higher position in the labour market comparing to men are not punished but even not rewarded.

This Index is geared to measuring gender equality between countries on the basis of four indicators, namely:

- An economic area that compares wage levels and access to skilled work;

- The education achieved is another area that focuses on access to basic education as well as access to higher education;

- The political area measures inequality between men and women at the highest level of political decision-making;

- The last indicator of this Index is health and provides information on the mean life expectancy, assuming that women enjoy a higher life expectancy than men (WORLD ECONOMIC FORUM, 2015).

Figure 1 shows the results for the Slovak Republic in the Global Gender Gap Index where individual countries are assessed on the basis of four indicators.

\section{Figure 1: Assessment of the Slovak Republic based on Global Gender Gap Index}

\section{Country Scores Compared}

Against sample average

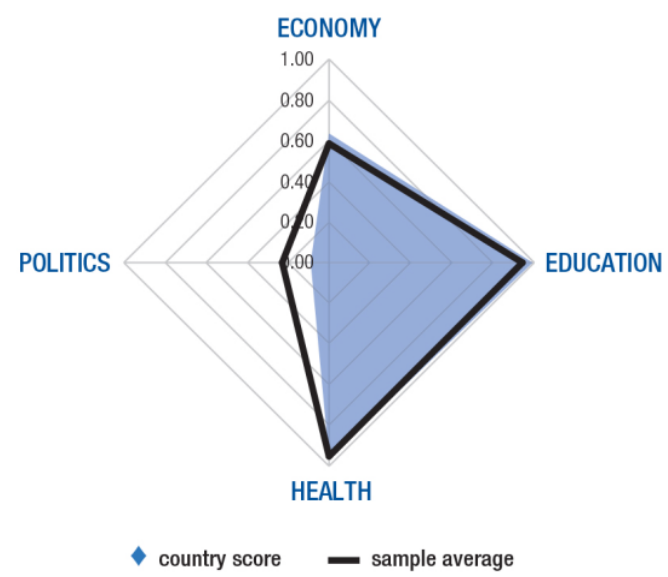

Against income group range and average

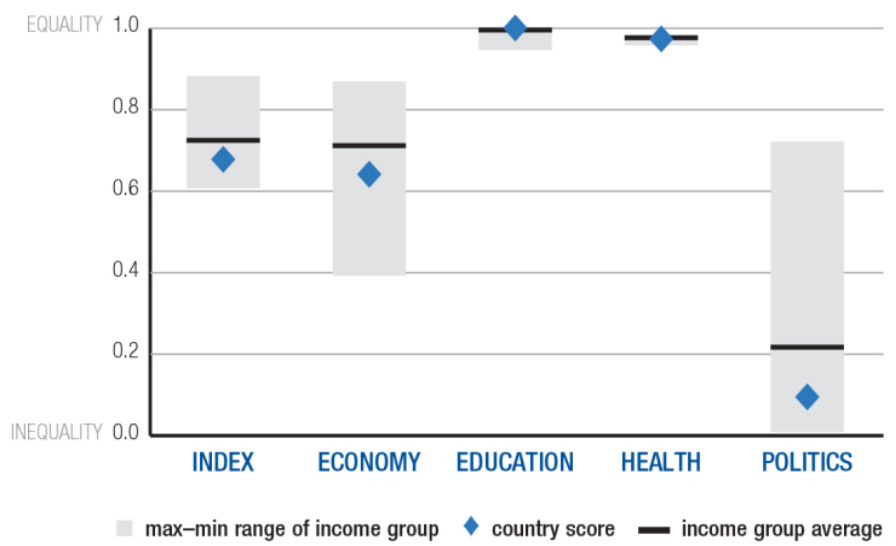

Source: WORLD ECONOMIC FORUM. Global Gender Gap Report: 2015. [cit. 2016-03-10] accessed online: <http://reports.weforum.org/global-gender-gap-report-2015/economies/\#economy=SVK> 
Currently the Index covers 145 of emerging economies. In 2015 the Slovak Republic has ranked 97th in the Global Gender Gap Index in 97th place out of 145 economies. This index is being developed since 2006 when the Slovak Republic ranked 50th out of 115 countries, marking a negative development. The biggest drop was recorded by the Slovak Republic in 2014, when it fell up to 16 ranks in one year, placing in $90^{\text {th }}$ spot. This was caused by economic and political factors. So far, the only positive results were achieved by the Slovak Republic in 2012, when it grew by two slots (from 72nd place to 70th place).

The development of the "economy" area has a volatile tendency, recording a decline for most years, but some years (such as 2008, 2010, 2011, 2012 and 2015) a growth has been recorded. After evaluating data from all of the past years, we have come to the conclusion that this pillar is developing negatively on the whole.

"Education" is another area included in the Index, which shows a positive development (0.005) compared to the "economy" area and thus helps to strengthen the Slovak Republic's position in the ranking vis-à-vis other countries. From 2008 to 2015 Slovakia has ranked in 1st position in comparison with the other 145 countries.

Another area assessed by the Index is "health". From 2006 to 2013, the values in this category remained unchanged. This has secured 1st place for Slovakia out of the other countries in the ranking. Only in 2014 has this figure dropped from 0.980 to 0.973 (resulting in 74th out of 142 ranks, while in in 2014 and in 2015 Slovakia ranked 79th out of 145 countries).

The last area assessed by the index is "politics", which also has a fluctuating tendency. The best ranking was achieved by the Slovak Republic in 2008, when it secured 71st place out of all ranked countries. In the last two years the development trend has been negative, when Slovakia ranked in 115th position out of the 145 countries. When taking into account data from all years, we can assume that the value of this indicator is positive (WORLD ECONOMIC FORUM, 2015).

\section{Conclusion}

In the Slovak Republic, a legislative framework is in place to regulate the equality of men and women in the labour market. Nevertheless, gender inequalities in the labour market still persist. In recent years, the situation in the Slovak labour market in the area of gender gaps has partially improved. These differences, however, are reflected, inter alia, in disadvantaging women, when it comes to the jobs available for them or wage levels, which still favour men. Women, especially at a certain age, choose a job that does not require much responsibility, and they also try to work in a company where they do not spend a substantial part of the day. Their main goal is to reconcile personal life and work life. 
ACKNOWLEDGEMENT: The paper is the outcome of scientific project VEGA No. 1/0001/16 'Súčasnost' a perspektívy zmien zamestnanosti a súvisiacich procesov $v$ kontexte napĺn̆ania cielov Európskej stratégie zamestnanosti .

\section{References}

BAROŠOVÁ, M. (2006). Monitoring rodovej segregácie na trhu práce - analýza dopadov transformačných zmien. Bratislava: Inštitút pre výskum práce a rodiny, 2006. s. 114.

BECKER, G. S. (1997). Teorie preferencí. Praha: Grada Publishing, 1997. s. 195. ISBN 807-1694630.

EURÓPA 2020. Sumár stratégie Európa 2020 [online]. [cit. 2015-10-22]. Dostupné na internete: $<$ http://ec.europa.eu/europe2020/europe-2020-in-a-nutshell/index_sk.htm>.

CHARTA ZÁKLADNÝCH PRÁV EURÓPSKEJ ÚNIE. (2000). [online]. Nice: 2000. [cit. 2015-10-22]. Dostupné na internete: <http://arc.eppgroup.eu/Activities/docs/charter_eu/sk.pdf>.

INŠTITÚT PRE VÝSKUM PRÁCE A RODINY. (2006). [online]. Bratislava: [cit. 2015-11-02]. Dostupné na internete: <http://www.ceit.sk/IVPR/images/IVPR/vyskum/2006/Barosova/Barosova-2006.pdf>.

MINISTERSTVO ŠKOLSTVA, VEDY, VÝSKUMU A ŠPORTU SR. (2015). Výročná správa o stave vysokého školstva za rok 2014. [online]. Bratislava: 2015. [cit. 2016-02-02]. Dostupné na internete: $<$ https://www.minedu.sk/vyrocne-spravy-o-stave-vysokeho-skolstva/>.

PIETRUCHOVÁ, O. (2007). Nedocenená práca žien: História, legislatíva a konceptualizácia rodového rozdielu v odmeňovaní. 1.vyd. Bratislava: Aspekt, 2007. s. 46-65. ISBN 978-808-5549-768

Rievajová, E. a kol. (2015). Trh práce - premeny a výzvy. Bratislava: Ekonóm, 2015. ISBN 978-80-2254061-2

ŠTATISTICKÝ ÚRAD SLOVENSKEJ REPUBLIKY. (2016). Databázy - STATdat. [online]. Bratislava: 2016. [cit. 2016-04-28]. Dostupné na internete: <http://statdat.statistics.sk/cognosext/cgibin/cognos.cgi?b_action=cognosViewer\&ui.action=run\&ui.object=storelD\%28\%22i42A8A014A6874 9 5596DC929810349606\%22\%29\&ui.name=Pracuj\%C3\%BAci\%20pod\%C4\%BEa\%20veku\%20[pr3 11

5qr]\&run.outputFormat=\&run.prompt=true\&cv.header=false\&ui.backURL=\%2fcognosext\%2fcps $4 \%$ 2f portlets\%2fcommon\%2fclose.html\#>.

WORLD ECONOMIC FORUM. (2015). The Global Gender Gap Report. 2015. 